\title{
9
}

\section{EXHIBITIONS AS A COLLABORATIVE RESEARCH SPACE FOR UNIVERSITY- MUSEUM PARTNERSHIPS}

\author{
Palmyre Pierroux, Birgitte Sauge, and Rolf Steier
}

Collaboration between partners in universities and museums is increasingly viewed as an important means of demonstrating the societal relevance of both research and practice in the GLAM sector (galleries, libraries, archives and museums). Recent studies have shown the significance of university-museum research collaborations in the context of advancing visitors' cognitive development in museum settings (Sobel \& Lipson, 2016), fostering the democratisation of knowledge through citizen projects in archives (Hetland et al., 2020), and producing novel experiences of art, science and cultural heritage through the co-design of innovative exhibition technologies in galleries (Drotner et al., 2019; Kenderdine, 2020). Approaches to modelling and implementing such partnerships has thus emerged as a topic in museum studies, with experimental museology conceptualised as mutually beneficial alignments between professional practices and academic discourses, balancing both museum curators and university researchers' interests and contributions.

A particular challenge in experimental museology, as we see it, is identifying and supporting partners' different aims and motivations as these unfold during various phases of a university-museum research collaboration. In her review of university-museum collaborations, Gaskins (2016) identified differing priorities, time frames, interaction styles and tensions in reconciling the implications and communication of research findings as sources of potential cultural conflicts. In museums, for example, directors, curators and educators may participate in research projects with universities to prioritise building new audiences, enhancing the quality of visitor experiences, developing visitors' knowledge, and advancing academic insights and professional expertise that keep their institutions relevant (Simon, 2016). In universities, researchers prioritise museums as powerful settings for studying informal learning (Sobel \& Lipson, 2016), but also an ideal space for developing theoretical concepts of embodied experience and meaning-making in the domains of science, art, architecture and other forms of cultural heritage 
(Christidou \& Pierroux, 2019; Leister et al., 2018; Steier, 2014; Tzortzi, 2015). In other words, expectations, tensions and interests among university-museum partners in research projects do not necessarily match but may nonetheless be negotiated.

In this chapter, we use three decision events from a design-based research project as rich illustrations of how trade-offs and benefits were negotiated and viewed by the respective partners, namely, two researchers at a university (first and third authors) and a curator in an architecture museum (second author). The aim of the chapter is to describe and analyse how our respective research and practice interests emerged, became foregrounded and overlapped over the course of nine months, in the design of an exhibition experiment at a national architecture museum. We present an analysis of these decisions and their implications for the research project from both museum and university perspectives. Based on the analysis we conclude that the decisions formed a collaborative research space that was owned by neither university nor museum but instead required a dynamic researcher positionality to shift between three research lenses. Moreover, as a collaborative exercise in critical reflexivity, the chapter demonstrates an equitable approach to identifying key dynamics of productive university-museum research collaborations. In conversation with perspectives on experimental museology, the following questions are investigated: what constitutes a collaborative research space in experimental museology? How do decision events in a design process shape - and become shaped by - collaborative research dimensions?

\section{Research lenses}

The project was organised to accommodate the different, but overlapping interests of project partners coming from different research traditions. Overall, there were shared interests in digital media and new knowledge practices in museums, and in exploring the communicative potential of virtual reality and immersive environments in architecture exhibitions (Kenderdine, 2020; White \& Chen, 2020). These interests stem from what has been identified as a gap between, on the one hand, contemporary 'born digital' architecture that is designed using virtual reality modelling and a realm of digital as well as analogue tools (Pierroux et al., 2019; Sauge, 2019), and on the other hand, architecture exhibition practices, which in museums still largely rely on the display of conventional analogue objects and representations like models, drawings and photos (Pierroux et al., 2019). This gap served as foreground for the curator's research interests and also framed the overall project aims: to explore new exhibition practices(Sauge, 2018a, 2018b, 2019) and how virtual reality might be designed and used to provide and enhance multisensory architectural experiences in museum exhibitions. The curator brought to the partnership both her research expertise as architectural historian and her practice expertise as senior curator at a national architecture museum. The university researchers' interests in the project centred on concepts of embodiment in meaning-making (Steier, 2014; Steier \& Kersting, 2019; Steier et al., 2015) and 
particularly in virtual and immersive environments. The university researchers' interests in the project centred on concepts of embodiment and how meaning-making is accomplished through interactions in virtual and immersive environments (Steier, 2014; Steier \& Kersting, 2019; Steier et al., 2015).

In addition to this research team, a curator colleague from the museum who specialised in education and digital media was a formal participant in the project, contributing a practice perspective on visitor studies. Other professionals formally engaged in the study included a lead architect at a prominent architectural firm, a virtual reality developer and a soundscape developer. The architect partner viewed the collaboration as an opportunity to build on earlier works commissioned for exhibitions and to explore disciplinary interests in body-nature relationships in architectural design. The architect's motivation in this study was to inspire visitors to think about how spaces formed in nature may be similarly experienced in architecture, heightening visitors' awareness of the body's dimensions and functions also when moving through virtual 'nature' and 'built' environments. The soundscape and VR developers' interests were more specialised in terms of technical issues, but were similarly focussed on how to enhance visitors' multisensory experiences through museum media design. While each of these partners brought their respective research interests into the collaboration, our focus is on the formal university-museum research partnership.

In keeping with the partners' interests described above, three research lenses were identified at the beginning of the project: exhibition practices, museum media and meaning-making. Each lens comprises a specific field of inquiry, and distinct sets of aims and questions were discussed, formulated and updated by all team members in a collaborative process that resulted in a shared living document. This document informed design decisions for the exhibition experiment but also aimed to guide research - both discipline-specific and interdisciplinary - that could advance practice in the different fields (Figure 9.1). During the design process, then, as key decisions were made by the team, the researchers purposefully drew on and traversed these three lenses in a 'collaborative research space' (Freeth

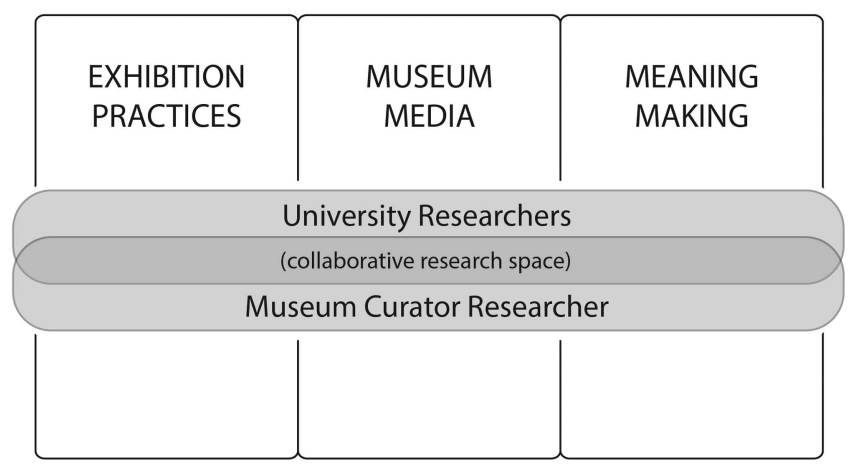

FIGURE 9.1 Research lenses in university-museum partnership. 
\& Caniglia, 2020) that was created and maintained through a 'self-consciously interdisciplinary practice' (Fitzgerald et al., 2012, p. 11). Specifically, the collaborative research space was defined by similar epistemic interests in how architectural environments may be modelled for museum exhibitions using virtual reality, in ways that foster visitors' experiential knowledge and embodied understandings of architecture. The project culminated in a full-scale 'blended reality' exhibition experience in an architecture museum and five weeks of visitor studies.

\section{Design-based approaches and collaborative research}

Research collaborations between universities and museums are often organised using some form of design-based approach, particularly when new technologies or learning activities are introduced and studied in exhibitions and galleries (Pavement, 2019; Samis, 2019; Stuedahl, 2019). There are different paradigms of design-based research in museums, each of which has 'professional theories' (vom Lehn et al., 2020) about visitor experience, design processes and the involvement of participants as collaborators. Design-based approaches and professional theories thus become critical tools and resources for partners during the imagining, planning and implementation of exhibitions (vom Lehn et al., 2020). Below we describe the design-based approaches within each research lens that were relevant for the partner collaboration.

\section{Exhibition practices and design-based research}

Changing exhibition practices and ensuing interests in how these may entail 'remodelling the museum as an institution' (Bjerregaard, 2020, p. 12) constitute the first paradigm of design-based research. In several early studies, both museum insider (Roberts, 1997), and embedded university outsider (Macdonald, 2002) positions were adopted to study how decisions were made among teams of museum staff and consultants in exhibition design processes. Both are ethnographic studies, illuminating how design decisions about exhibition components (for example, an exhibition's content, representations and resources) were negotiated by an exhibit team to incorporate the interests of different stakeholders, disciplinary knowledge and new types of expertise. Ethnographic approaches include the voices and actions of the collaborators and allow for unpacking the 'belief systems, behaviours, and relationships of the exhibit team' (Roberts, 1997, p. 10). More interventionist methods have also been used to study change in exhibition practices, for example, by introducing new arenas for visitor participation in rethinking the design of activities, resources and the role of museums (Pringle, 2019).

According to Kenderdine (2020), the GLAM sector (galleries, libraries, archives and museums) is renewing research interests in 'the role of the museum as a site in which knowledge processes take place and are interrogated' (Kenderdine, 2020, p. 306). In the past decade or so, for example, exhibition practices have been 
explored as experiments and reflexive tools for museum curators and academics within the museum (Bjerregaard, 2020; Macdonald \& Basu, 2007). Here, exhibition making processes are made visible to consciously question concepts and practices of representation, narrativity and experience, among other topics (Basu \& Macdonald, 2007), with 'a focus on the capacity of exhibitions to generate research in and through themselves' (Bjerregaard, 2020, p. 1). In Norway, the turn to questioning expertise and meaning-making within their own museums based on reflexive studies of exhibition design practices has been termed by university museum researchers as 'the new knowledge production' (Maurstad \& Hauan, 2012). A characteristic of this design-based approach is that it focuses on processes and questions other than those posed by 'research in the conventional sense of the term: systematic data gathering and careful observation and analysis in order to test a hypothesis' (Bjerregaard, 2020, p. 12). The project discussed in this chapter thus differed from the 'exhibitions as research' concept outlined by Bjerregaard (2020) because it included both 'conventional' research methods and a multi-professional collaboration that incorporated both insider and outsider researcher roles. Charting how a collaborative design-based research space figures into the territory of this 'new knowledge production' is one of the challenges explicitly addressed in the project and in this chapter, that is, to understand how the concept of 'exhibitions as research' may be stretched across epistemic interests, partner relations and institutional practices.

We nonetheless share Bjerregaard's acknowledgement of institutional challenges in implementing 'the kind of experimental museology that seems to emerge from this approach' (Bjerregaard, 2020, p. 1). Bjerregaard points to potential tensions when museum business models, with an emphasis on efficiency, need to 'accommodate these unpredictable processes within the larger 'museum machinery,' noting that 'if we want to turn exhibitions into research, the exhibition will not progress according to the most efficient plan, but according to the curiosity and serendipity involved in finding out.... It is, in practice, a re- modelling of the museum as an institution' (Bjerregaard, 2020, p. 12). In sum, design-based approaches to studies of exhibition practices may adopt or move between insider and outsider researcher positions; to understand how knowledge is produced and represented, but also to critically examine how exhibition practices shape - and are shaped by - the museum as an institution.

\section{Museum media and design-based research}

Second, as part of larger trends and developments in museum media research (Drotner \& Schrøder, 2013; Drotner et al., 2019; Parry, 2010), it is possible to identify user-centred design methods from informatics and computer science (Hornecker \& Ciolfi, 2019), which foreground studies of technological development and the social and biological mechanisms of information processing. In general, these design-based approaches are future-oriented (Vavoula \& Sharples, 2007), focussed on how technologies may be designed for users' real and 
envisioned needs and behaviours in museum settings. In human-computer information (HCI) studies in museums, it has not been unusual for prototypes to be developed and tested by university researchers with limited participation of museum staff or visitors, with publications reporting on design rationales, evaluation outcomes and insights regarding design features (Hanlee, 2020; Hornecker \& Ciolfi, 2019). Although the value of such experimentation with digital media is debatable in terms of innovation in museum practices (Hornecker \& Ciolfi, 2019; Pavement, 2019; Samis, 2019), it is clear that technology-oriented research, carried out over decades in museum settings, has been instrumental in shaping museum mediascapes as they are experienced today, in the digital age (Hornecker \& Ciolfi, 2019; Kidd, 2014; Parry, 2007; 2010).

Significantly, increased collaboration between museum staff and university researchers in design processes has been key to the transformational impact of this research, playing a role in some museums becoming early adopters of new museum media (Freeman et al., 2016; Samis, 2019). As noted by Knell over a decade ago: 'The opportunities provided by technology have developed so rapidly and become so pervasive that these workers are beginning to emerge from their backroom documentation projects to join up with academic researchers from leading university computer science departments, in order to construct a roadmap that will take museums into the future' (Knell, 2010, pp. 445-46). Universitymuseum research partnerships (Kenderdine, 2020), participatory design methods involving visitors and stakeholders (Simon, 2010) and more recent trends of do-ityourself (DIY) approaches to exhibition design and research (Ecsite, 2018) may thus be viewed as emerging, in part, from such early 'joining up' practices. This tradition of research on new museum technologies nonetheless remains focused on experiments with clear criteria for design and the evaluation of outcomes rather than the transformative expansion of museum practices.

\section{Meaning-making and design-based research}

A third paradigm of design-based approaches is seen in areas of research that focus on meaning-making in museums, as part of a wider interpretive endeavour in audience engagement. In studies anchored in the learning sciences, such methodological approaches are referred to as educational design research (EDR) (Anderson \& Shattuck, 2012; Barab \& Squire, 2004; McKenney \& Reeves, 2018). Beginning in the early 1990s (Brown, 1992) and based on theories in developmental psychology (Vygotsky, 1978; 1981), researchers argued the need for studies of learning activity in actual contexts and natural settings. In contrast to academic laboratory settings, this approach emphasised the design of iterative interventions - planned changes - in existing practices (for example, introducing new digital resources or instructional designs in classrooms) to study their impact on learning processes and subsequently identify how practices could be improved.

In museum-related learning research, EDR has emphasised the participation of museum staff and visitors in design processes. For researchers, a participatory design 
process provides deeper understandings of the complexities of meaning-making practices in the specific museum setting (Simon, 2010; Smørdal et al., 2014; Stuedahl, 2019). In science centres, for example, researchers have collaborated on exhibit designs with museum staff to then systematically study how families, young people, students and children learn conceptual knowledge or use evidence to reason about scientific phenomena (Bakken \& Pierroux, 2015; Krange et al., 2019; Sobel \& Lipson, 2016). Changes are made to the exhibits based on findings and new conjectures, in an iterative collaborative design process that is informed by both research and practice. In art and cultural heritage museums, researchers and curators have similarly collaborated with other experts on exhibit designs that facilitate visitors' interpretation and meaning-making, with researchers systematically studying visitors' embodied, multisensory and social interactions to advance learning theory (Steier, 2014; Steier et al., 2015), and curators then integrating findings in the design of new interpretive practices (Pierroux et al., 2014). In this study, EDR methods were used to understand how features of the museum setting, including embodied, social interactions in a blended reality environment, mediated visitors' experiences and understandings of architecture.

Together, these three paradigms of design-based approaches to research in museums, exhibition practices, museum media and meaning-making, each with distinct traditions of involving research collaborators, comprised the collaborative research space for this study. Therefore, an important challenge for the universitymuseum research team was practicing what Freeth and Vilsmaier (2020) call a dynamic researcher positionality to shift between these three research lenses, assuming insider and outsider roles at different moments during the design of the exhibition experiment.

\section{Analytical approach}

The analytical approach in this study is based on critical-reflexive analyses of our respective university-museum research practices (Freeth \& Vilsmaier, 2020; Gaskins, 2016; Phillips et al., 2013), linking researcher positionality to empirically rich descriptions of decision events in the design of the exhibition components. The term decision event is used to highlight the temporal, collaborative aspects of negotiating the design and implementation of exhibition components. An 'event' in this sense is not a precise moment in time but describes the trajectory and consequences of a particular team decision. Based on notes, documents and recordings of project meetings, three narratives are presented to demonstrate how decisions regarding key exhibition components foregrounded a particular research lens, to describe how differences in knowledge interests were tackled in relations between researchers and partners, and to consider the implications these may have had for the knowledge that was co-produced (Phillips et al., 2013). In keeping with Roberts' (1997) critical-reflexive approach, each narrative begins with a close look at one exhibition component, presenting an account of its initial design or idea and the debates surrounding its development. The narrative identifies points 
of agreement, contention and debate that emerged in the collaborative research space, but also illustrates design issues relevant to each research lens: exhibition practices, museum media and meaning-making.

\section{Research lens: exhibition practices}

The first decision event is viewed from a research lens on exhibition practices, specifically, the selection of the exhibition space. The team initially planned the research as a series of iterative experiments in a small, concrete, curtained space $\left(10 \mathrm{~m}^{2}\right)$ that was somewhat secluded and available in the architecture museum. From the museum curator perspective, the limited size of the initial room was seen as positive in the sense that the design of physical elements would not demand great effort from the museum's own staff and it would be possible to realise within the project's budget. The black box character was also considered appropriate for the use of VR, since architectural qualities were envisioned as being experienced primarily within a designed virtual environment, through a headset. From the university researchers' perspective, an important affordance of this inconspicuous space in the museum was the temporal dimension associated with design-based research, which requires iterative cycles of development and refinement. The plan was to develop prototypes and iterations of the exhibition onsite for a period of several months, with the exhibition space closed off for development work and then opened periodically to invite visitors into the space for empirical studies. However, drawbacks of the space were noted by the team as well. The high walls were concrete, covered with black curtains, and the space had two openings without doors. These features had implications for the room's acoustics and would be a challenge for planned experiments with sound. The limited floor space $\left(10 \mathrm{~m}^{2}\right)$ also constrained the number and size of physical elements that could be included in the experiment, particularly important to the architect. There were curatorial concerns as well, in terms of how the planned use might intervene in the experience of the larger adjacent exhibition. Finally, there would be little space for a video camera to use in visitor studies, and not much room for participants other than the person wearing the VR headset.

About two months into the nine-month design process, the curator presented to the team a new option of using the museum's large and most prominent gallery space $\left(100 \mathrm{~m}^{2}\right)$, designed by the prominent Norwegian architect Sverre Fehn for the exhibition experiment (Figure 9.2). A gap had become available in the museum's exhibition program that would allow use of the Fehn gallery, and the curator had negotiated with museum leadership for an extended exhibition period that allowed for the visitor research. For the curator, and for the architect, the new space represented an opportunity to design a comprehensive exhibition installation with spatial and aesthetic qualities, accompanied by information to the public (e.g., newspaper announcements, press, signage in the exhibition). From her perspective, a realistic and interesting exhibition situation could be created rather than a 'laboratory for experiments' that had no specific architectural qualities in itself. 


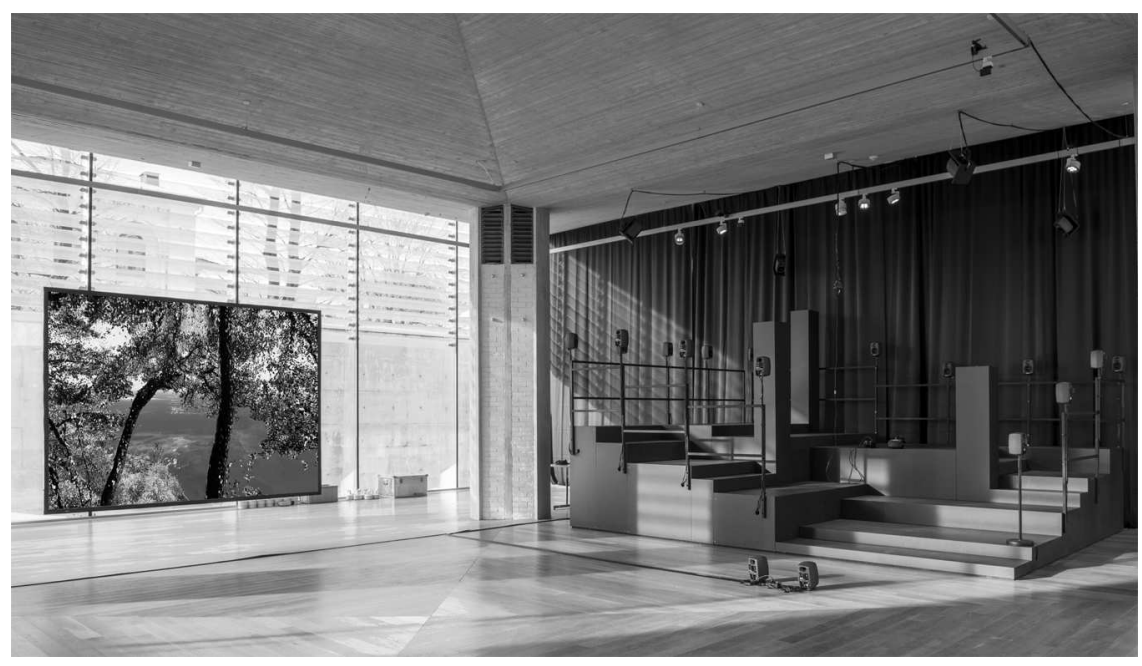

FIGURE 9.2 Exhibition experiment in Fehn gallery. Photo courtesy of Nasjonalmuseet.

A focus on content - the disciplinary architectural perspective/framing that is the basis for all exhibitions in an architecture museum - could thus be upheld. The exhibition installation could include elements that were thoughtful, thoroughly designed, and well composed, in a space that stirred visitors' curiosity and also allowed them to experience Fehn's architecture. These are qualities that the curator values and wants architecture exhibitions to have. From her perspective, the architect would also have greater opportunity to explore how his firm's work could be communicated in exhibition media, which she was interested in as a researcher.

For the university researchers, moving the exhibition to the larger space was a clear demonstration of museum support for the project, validating the research partnership. Increased space would also allow for the design of a greater range of sensory experiences, primarily by incorporating more movement and sound. However, moving the exhibition from a more secluded area to such a prominent location had implications for how the project would be perceived by visitors, with higher expectations for the quality of the experience and the robustness of the technology and other features. Such high expectations run counter to the more experimental nature of an educational design research project, which asks visitors to not focus on an unfinished structure or handwritten note, but instead imagine what the experience could be like. Therefore, instead of inviting small groups of visitors into the space periodically over several months to iteratively research and design exhibition components, the testing of components was conducted at the architecture studio with recruited participants. Ultimately, since it was assumed that the new location would attract a larger audience than initially planned, an 'experimental' framing was preserved by using texts and announcements explaining to visitors that the exhibition was part of a research project and that 
visitors' experiences would be asked to complete a questionnaire after their visit. Another consequence of the change in venue was that plans for collecting video data and interviews using recruited participants were condensed to an intense fiveday period just prior to the public opening of the exhibition. A discussion of findings from these visitor studies is outside the scope of this chapter.

The change of venue decision event meant that university researchers needed to compromise on the EDR method of iterative experimentation. Although the exhibition was presented as an experiment to the recruited participants and the general public, it was in the form of a finished experiment rather than interventions based on incremental changes and revised conjectures (McKenney \& Reeves, 2018). While the curator acknowledged that the exhibition could no longer be conceptualised as a 'laboratory for experiments,' this concession was in her view offset by the advantages of being able to design an exhibition with the same kind of professional attention to aesthetics and disciplinary content that curators, visitors and colleagues value and expect from a museum, and would ultimately contribute to the quality of data collected during visitor studies. The curator's disciplinary interests in architecture, digital media and representation in exhibition practices were clearly foregrounded in this decision, aligned more with 'exhibition as research' traditions within the museum (Bjerregaard, 2020) that are oriented to the development of the curator's academic discipline (Brenna, 2012). The decision event, for example, afforded the curator close dialogue with the architect partner during the design process about the development of architectural concepts, including spatial and structural considerations. This type of insight represented crucial knowledge for her, both as architecture historian and as curator interested in contemporary architecture exhibition practices. However, by also championing the university researchers' use of 'conventional research methods' (Bjerregaard, 2020) to study visitors in a prominent exhibition space, the collaborative research space became anchored within the museum as well, as a new experimental museology practice. In sum, there was shared acceptance among university and museum research partners of the respective trade-offs, even while these were valued somewhat differently; the collaborative research space accommodated the negotiation of a dynamic researcher positionality (Freeth \& Vilsmaier, 2020).

\section{Research lens: museum media}

The second decision event is viewed from a research lens on museum media and consisted of a commitment to experiment with visitors wearing tracking sensors in the exhibition design. Previous use of VR technology by our architect partner relied on clients teleporting through an architectural model by clicking a button on a controller. Based on demonstrations and the expertise of the VR developer on staff at the architectural firm's office, the team was introduced to the idea of tracking motion and movement in the exhibition setting using sensors attached to the body. The technology, though new and mostly untried in Norway, would enable greater interaction with physical objects while in the virtual environment, 
such as sitting in a chair or navigating steps, as well as allow for movement and a broader range of sensory experiences. The decision was risky, however, in terms of time needed for procuring equipment, designing visualisations, testing tracking quality, precision and robustness and coordinating design issues with the architect and sound developer.

From the curator's perspective, incorporating movement in the blended reality exhibition would enhance the physical, multisensorial and temporal experience of real architectural space, and was seen as the most relevant way of breaking with existing temporal and perceptual experiences of architecture in exhibitions, whether moving between displays of objects, two-dimensional materials or 1:1 models of building details. Neither should the visitor experience be based on walking, standing, or turning on a flat floor in a $4 \times 4 \mathrm{~m}^{2}$ space while clicking a handheld device to move through virtual realities, as this may be seen as merely extending a visually based experience. Instead, the design should be in line with the architect's philosophy about the body's memory and corporeal experience of architecture, which could only be realised in a full-scale and fully immersive installation. The use of sensors, mounted on feet and waist and connected by a tracking module in the ceiling, was thus crucial for realising the envisioned design, correlating the experience of the physical setting in which the visitors moved (Figure 9.2) with the two virtual worlds, nature and architecture (Figure 9.3), that the visitors saw and heard in the headset, 'toggling' between them using a handheld controller. The architect saw the possibility of aligning 1:1 models of these two virtual realities by simplifying and abstracting some forms while exactly matching other contours for navigation and conceptual purposes. Exact correlation between these virtual contexts and the built environment was also essential, both for the safe physical navigation of the exhibition and for an optimal understanding of the nature/architecture relations that one toggled between.

From the university researchers' perspective, the opportunity to introduce mobility through motion-tracking sensors created an exciting opportunity to include movement and embodied experience in the empirical agenda of the study. Inviting visitor movement and exploration in a bended reality setting meant a potential contribution to embodiment research in museum contexts, as well as to

(a)

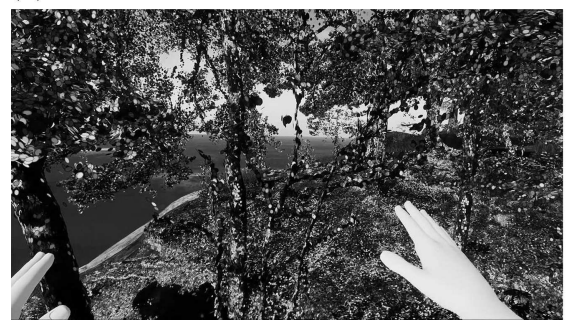

(b)

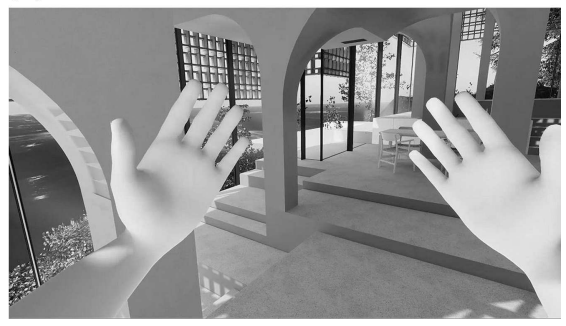

FIGURE 9.3 Virtual views of nature (left) and architecture (right) as seen in headset, from same physical orientation. 
newer studies of movement, touch and gesture in the learning sciences. A consequence of this decision event for the university researchers was including a focus on movement and mobility in the research questions and in the survey and interview questions that were posed to visitors.

The decision event to use sensor-tracking technology was thus central to interests of both research partners, and the narratives above highlight how these interests stem from and relate to different disciplinary traditions in interesting ways. The study of embodiment and movement in museum exhibitions, from a learning science perspective, is linked to explorations of how bodily orientations and gestures figure into processes that foster intersubjectivity, joint attention and meaning-making in virtual and physical environments. Contemporary architecture theory explores how human experience and understanding of architecture is intertwined with movement and all of the senses, through the body's memory and corporeal experience of place and being in the world (Pallasmaa, 2005). In this sense, the museum media research lens, which introduced qualitatively new types of interactions with architecture, was perhaps most crucial in creating the kind of fruitful interdisciplinary collaborative research space that all partners aim for when collaborating across institutions, enriching and expanding respective disciplinary ideas, methods and traditions. However, the researchers also had to largely rely on the technology experts and architect partner for the design of the museum media exhibition components and thus a significant part of the visitor experience. Consequently, the division of labor in the design of this exhibition component was more clear cut than collaboration on other components; there was not a strong overlap of skills for this specialised work. In a museum media research lens that foregrounds technical and technology-oriented design work, both university and museum researchers assumed a more limited collaborative role, involved mainly in testing and evaluating (Hornecker \& Ciolfi, 2019).

\section{Research lens: meaning-making}

The third decision event is viewed from a research lens on meaning-making and the agreement among partners to design a virtual reality visitor experience that was social, interactive and sharable. The decision about this exhibition component is not neatly identifiable in terms of a specific point in time, but was a gradual development over the course of conceptual work related to the design. The architect presented his interests in body-space relationships in terms of how individuals experience their surroundings through movement, and this individual focus naturally carried over into the team's initial design discussions. However, the university researchers emphasied tshe importance of a sociocultural perspective on meaning-making and were thus interested in how the exhibition could be designed to address the problem of how to allow visitors to share and develop interpretations, understandings and reflections through talk and social interaction during VR experiences in museums (see for example Parker \& Saker, 2020). For this reason, it was agreed that the design of the exhibition experience would be based on visitor pairs. 
Moreover, in designing the empirical studies, the university researchers aimed to collect rich data about visitor experiences, including reflections after their visit but most importantly their in-the-moment experiences of being in the blended reality environment. Accordingly, the decision to design the experience as social meant that pairs of visitors would be able to discuss their experiences with each other as they took turns exploring the space. From an empirical perspective, visitor talk would thus be visible (hearable) to the researchers, and could be recorded using video cameras and analysed as data. The outcome of this decision event was an exhibition experience that required two visitors, alternating between roles as viewer and as companion. As mentioned, analyses of the visitors' meaning-making is not in focus in this chapter.

On the museum's side, there was support for designing a social experience since the museum had data that visitors overwhelmingly visit with friends or family the museum visit was a social activity. There was also a general interest in collecting research data on how visitors experience architecture exhibitions. The museum had previously conducted a smaller study based on interviews with randomly selected visitors in the permanent exhibition and viewed the research collaboration as an opportunity to collect a completely different type of dataset observations, recordings, interviews, questionnaire responses and VR tracking recordings. To accommodate meaning-making research interests in both institutions, the university researchers worked closely with the education curator at the museum to develop a questionnaire for all visitors. The 22 questions were formulated to provide data relevant to each of the three research lenses and particularly to be relevant for museum practice. Questions that asked visitors to evaluate their exhibition experiences as pairs, their understanding of the content and whether they would recommend the exhibition to a friend are examples of how the museum's practice-based interests were accounted for in the data collection (Biuso, 2020).

For the university researcher, this decision event involved taking a theoretical stance that ensured relevant data for publishing research articles based on studies from the exhibition experiment. For the curator, there was a belief that the data was important for answering questions the museum is asking itself: who is the audience of exhibitions in architecture museums in the twenty-first century? And how do we engage these audiences? Therefore, the involvement of the education curator was crucial to maintaining meaning-making as a research lens that was relevant for both museum and university partners. In addition to participating in the planning and implementation of the questionnaire, she did much of the work to recruit participants with different types of architectural and VR expertise, different ages and different genders for the video-recorded visits and interviews that were led by the university researcher. She also participated in planning the visitor experience, hiring and training museum facilitators, for example, who familiarised visitors with the VR equipment and monitored their visit.

The decision event for this exhibition component, as with the others, had practical and technical design implications for all of the partners. Companions, for 
example, meant that visitors could feel safe moving around the installation without being concerned about tripping on cables or stumbling because of a potential misalignment between the virtual and physical scenes. This safety aspect meant that visitors within the VR scene could be more fully immersed in the environment, trusting that their partner would stop them from bumping into a wall or falling off a step. A soundscape design that was both a shared experience (ambient sounds projected through exhibition speakers) and an individual experience (additional sounds in open headset) and the installation of a large screen to share a viewer's virtual experience (Figure 9.2) are further examples of how foregrounding one partner's research interests - here, the university partner - raises a range of research and design issues for other partners.

\section{To sum up}

A premise of experimental museology is that museums will achieve greater societal relevance through closer alignments between professional practices and academic discourses in research production. In this chapter, these alignments were explored across institutions, as researchers and professionals from a museum and a university collaborated on an exhibition experiment in an architecture museum. As a case study of experimental museology, the project proved beneficial and relevant for visitors, museums and society in different ways. First, in terms of new research-based practices, the national museum involved visitors in a new exhibition practice an exhibition experiment contributing to policy aims for greater openness, access and visitor participation in museum practices. Reviews in national newspapers and magazines were particularly positive to involving the public in a research experiment in the museum (see for example Henriksen, 2018). The architecture firm developed new professional practices related to the use of $\mathrm{VR}$ in design work for public buildings, architecture exhibitions and other commissions, as well as new perspectives on involving 'users' in shaping and evaluating the firm's architectural projects. Second, in terms of innovation, the project produced a new creative use of tracking sensor technology as museum media in architecture exhibitions, contributing to qualitatively new experiences of the body's movement through nature and architecture and new understandings of the relations between them. Based on the curator's international network and a conference presentation of the 'co-production' approach in this project (Sauge, 2018c), the architecture firm and the museum were invited to further develop the experiment as a work to be shown in a new exhibition titled 'The architecture machine: The role of computers in architecture' at the Architekturmuseum der Technische Universität München in the autumn 2020. A proposal is also underway for acquiring the exhibition experiment as a 'work' for the national museum's permanent collection. Third, the empirical studies, still underway, have contributed new insights into visitors' interactions and meaningmaking in blended reality environments, among other topics (Biuso, 2020; Pierroux et al., 2019; Sauge, 2018b; Steier, 2020). In these very concrete ways, then, the case demonstrates the potential and value of experimental museology for transforming 
institutional and professional practices, developing innovative tools and media, and contributing new research to an interdisciplinary field.

This chapter also contributes to studies of how collaboration on exhibition designs is accomplished by teams with members from museums, universities and firms. Based on our own participation in such a team, we have demonstrated how decision events in a design process shape - and become shaped by - different partner interests. To analyse the research process, we introduced the concept of a collaborative research space to describe partner relations and differing knowledge interests, emphasising the need for a 'dynamic researcher positionality' (Freeth \& Vilsmaier, 2020). A collaborative research space challenges long traditions of research on museums and museum practises as the domain of university academics and not a relevant topic of study for curators. It also breaks with traditions of curators conducting research within the museum on topics related to their fields of specialisation, the collections, or their own exhibition practices. Although these traditions share interests in experimenting with collaboration, design-based methods and exhibition research, an experimental museology also requires, in our view, a critical-reflexive practice for analysing differing knowledge interests among partners and how these may impact the knowledge that is produced. Finally, as an extension of the collaborative research space described in this study, the narratives above also represent an exercise in 'collaborative critical reflexivity.' In this sense, this chapter serves as both discussion - and product - of an experimental museology.

\section{Acknowledgements}

This research was funded by The Research Council of Norway, Kulmedia programme, project \#247611. We thank Kevin Crowley and Karen Knutson, University of Pittsburgh, for discussions with the partner team during the project. We also gratefully acknowledge the essential contributions of Thomas Liu and the architect team at Atelier Oslo, education curator Anne Qvale at National Museum of Art, Architecture and Design, VR developer Ole Petter Larsen at Atelier Oslo, and researcher and sound developer Jøran Rudi at Notam.

\section{Bibliography}

Anderson, T., \& Shattuck, J. (2012). Design-based research: A decade of progress in education research?, Educational Researcher, 41(1), 16-25.

Bakken, S. M., \& Pierroux, P. (2015). Framing a topic: Mobile video tasks in museum learning. Learning, Culture and Social Interaction, 5, 54-65.

Barab, S. A., \& Squire, K. D. (2004). Design-based research: Putting a stake in the ground. Journal of the Learning Sciences, 13(1), 1-14.

Basu, P., \& Macdonald, S. (2007). Introduction: Experiments in exhibition, ethnography, art and science. In S. Macdonald \& P. Basu (Eds.), Exhibition experiments (pp. 1-24). Blackwell. 
Biuso, E. (2020). Space, place and presence in a virtual architecture exhibition. (Unpublished master's thesis). University of Oslo, Norway.

Bjerregaard, P. (2020). Introduction: Exhibitions as research. In P. Bjerregaard (Ed.), Exhibitions as research: Experimental methods in museums (pp. 1-16). Routledge.

Brenna, B. (2012). Gjort er gjort: Universitetsmuseene post factum [Done is done: The university museums post factum]. In A. Maurstad \& M. A. Hauan (Eds.), Museologi på norsk: Universitetesmuseenes gjøren[Museology in Norwegian: The university museums' practices] (pp. 231-237). Akademika.

Brown, A. L. (1992). Design experiments: Theoretical and methodological challenges in creating complex interventions in classroom settings. Journal of the Learning Sciences, 2(2), 141-178.

Christidou, D., \& Pierroux, P. (2019). Art, touch and meaning making: An analysis of multisensory interpretation in the museum. Museum Management and Curatorship, 34(1), 96-115.

Drotner, K., \& Schrøder, K. (Eds.). (2013). Museum communication and social media: The connected museum. Routledge.

Drotner, K., Dziekan, V., Parry, R., \& Schrøder, K. C. (2019). Media, mediatisation and museums: A new ensemble. In K. Drotner, V. Dziekan, R. Parry, \& K. C. Schrøder (Eds.), The Routledge handbook of museums, media and communication (pp. 1-12). Routledge.

Ecsite. (2018). SPARKS capture learning report. https://www.ecsite.eu/sites/default/files/d4. 3_sparks_capture_learning_report_final_0.pd

Fitzgerald, D., Brunner, E., Koellinger, P., \& Navarro, A. (2012). 'The good, the bad and the ugly': Understanding collaboration between the social sciences and the life sciences. Strategic Workshop Report. Standing Committee for the Social Sciences. http://archives.esf. org/fileadmin/links/Social/Publications/TheGoodThe_BadTheUgly.pd

Freeman, A., Adams Becker, S., Cummins, M., McKelroy, E., Giesinger, C., \& Yuhnke, B. (2016). NMC Horizon report: 2016 museum edition. The New Media Consortium. https://www.learntechlib.org/p/182007/

Freeth, R., \& Vilsmaier, U. (2020). Researching collaborative interdisciplinary teams: Practices and principles for navigating researcher positionality, Science and Technology Studies, 15, 247-261.

Freeth, R., \& Caniglia, G. (2020). Learning to collaborate while collaborating: Advancing interdisciplinary sustainability research. Sustainability science, 15(1), 247-261.

Gaskins, S. (2016). Collaboration is a two-way street. In D. Sobel \& J. L. Lipson (Eds.), Cognitive development in museum settings: Relating research and practice (pp. 151-170). Routledge.

Hanlee, I. (2020). Human-centred design in digital media. In H. Lewi, W. Smith, D. vom Lehn, \& S. Cooke (Eds.), The Routledge international handbook of new digital practices in galleries, libraries, archives, museums and heritage sites (pp. 319-325). Routledge.

Henriksen, A. (2018, 21 February). Slik blir fremtidens museumstur [The museum visit of the future], Aftenposten. https://www.aftenposten.no/osloby/i/rLdL5w/Slik-blirfremtidens-museumstur

Hetland, P., Pierroux, P., \& Esborg, L. (Eds.). (2020). A history of participation in museums and archives: Traversing citizen science and citizen humanities. Routledge.

Hornecker, E., \& Ciolfi, L. (2019). Human-computer interactions in museums. Synthesis lectures on human-centered informatics, 12(2), i-171.

Kenderdine, S. (2020). Hemispheres: Transdisciplinary architectures and museumuniversity collaboration. In H. Lewi, W. Smith, D. vom Lehn, \& S. Cooke (Eds.), The 
Routledge international handbook of new digital practices in galleries, libraries, archives, museums and heritage sites (pp. 305-318). Routledge.

Kidd, J. (2014). Museums in the new mediascape: Transmedia, participation, ethics. Ashgate.

Knell, S. J. (2010). The shape of things to come: Museums in the technological landscape. In: R. Parry (Ed.), Museums in a digital age (pp. 445-463). Routledge.

Krange, I., Silseth, K., \& Pierroux, P. (2019). Peers, teachers and guides: A study of three conditions for scaffolding conceptual learning in science centers. Cultural Studies of Science Education, 15(1), 241-263.

Leister, W., Tjøstheim, I., Norseng, P. G., Joryd, G., Bagle, E., \& Sletten, H. T. (2018). Digital storytelling and engagement in exhibitions about shipping. Norsk museumstidsskrift, 4(2), 50-72.

Macdonald, S. (2002). Behind the scenes at the science museum. Berg.

Macdonald, S., \& Basu, P. (Eds.). (2007). Exhibition experiments. Blackwell.

Maurstad, A., \& Hauan, M. A. (Eds.). (2012). Universitetsmuseenes gjøren: Om redskaper og relasjoner i museenes kunnskapsproduksjon [Done is done: On tools and relations in museum knowledge formation] In A. Maurstad \& M. A. Hauan (Eds.), Museologi på norsk: Universitetesmuseenes gjøren [Museology in Norwegian: The university museums' practices] (pp. 13-31). Akademika.

McKenney, S., \& Reeves, T. (2018). Conducting educational design research. Routledge

Pallasmaa, J. (2005). The eyes of the skin: Architecture and the senses. Wiley.

Parker, E., \& Saker, M. (2020). Art museums and the incorporation of virtual reality: Examining the impact of VR on spatial and social norms. Convergence. https://doi.org/ $10.1177 / 1354856519897251$

Parry, R. (2007). Recoding the museum: Digital heritage and the technologies of change. Routledge.

Parry, R. (Ed.). (2010). Museums in a digital age. Routledge.

Pavement, P. (2019). The museum as media producer: Innovation before the digital age. In K. Drotner, V. Dziekan, R. Parry, \& K. C. Schrøder (Eds.), The Routledge handbook of museums, media and communication (pp. 31-46). Routledge.

Phillips, L., Kristiansen, M., Vehviläinen, M., \& Gunnarsson, E. (2013). Tackling the tensions of dialogue and participation: Reflexive strategies for collaborative research. In L. Phillips, M. Kristiansen, M. Vehviläinen, \& E. Gunnarsson (Eds.), Knowledge and power in collaborative research: A reflexive approach (pp. 1-18). Routledge.

Pierroux, P., Qvale, A., Steier, R., \& Sauge, B. (2014). Posing with art: Researching and designing for performative acts of interpretation. In Museums and the Web 2014, 2-5 April, Baltimore, MD. https://mw2014.museumsandtheweb.com/paper/posing-withart-researching-and-designing-for-performative-acts-of-interpretation-2/

Pierroux, P., Qvale, A., Steier, R., \& Sauge, B. (2019). Studying visitors' exhibition experiences in a virtual reality environment. In Visitor Studies Association Annual Conference, Detroit, 10-13 July.

Pierroux, P., Steier, R., \& Sauge, B. (2019). Imagining, designing and exhibiting architecture in the digital landscape. In A. Mäkitalo, T. Nicewonger, \& M. Elam (Eds.), Designs for experimentation and inquiry: Approaching learning and knowing in digital transformation (pp. 87-109). Routledge.

Pringle, E. (2019). Rethinking research in the art museum. Routledge.

Roberts, L. C. (1997). From knowledge to narrative: Educators and the changing museum. Smithsonian Institution Press.

Samis, P. (2019). Revisiting the utopian promise of interpretive media: An autoethnographic analysis drawn from art museums, 1991-2017. In K. Drotner, V. Dziekan, 
R. Parry, \& K. C. Schrøder (Eds.), The Routledge handbook of museums, media and communication (pp. 47-66). London: Routledge.

Sauge, B. (2018a). BIM, a discussion in Norwegian competitions. In M. Theodorou \& A. Katsakou (Eds.), Competition grid: Experimenting with and within architecture competitions. RIBA Publishing.

Sauge, B. (2018b). The forest in the house: Architecture exhibition experiment as a designbased research practice partnership. In ICAM 19: Migrating Ideas, Copenhagen, 9-13 September.

Sauge, B. (2018c). CONNECT: Enabling exhibition co-production. In ICAM 19: Migrating Ideas, Copenhagen, 9-13 September.

Sauge, B. (2019). Digital design media in Norwegian architects' current practice: Survey 2016-2017. Oslo, Norway: National Museum of Art, Architecture and Design.

Simon, N. (2010). The participatory museum. Museum 2.0.

Simon, N. (2016). The art of relevance: Museum 2.0.

Smørdal, O., Stuedahl, D., \& Sem, I. (2014). Experimental zones: Two cases of exploring frames of participation in a Dialogic museum. Digital Creativity, 25(3), 224-232.

Sobel, D., \& Lipson, J. L. (Eds.). (2016). Cognitive development in museum settings. Routledge.

Steier, R. (2014). Posing the question: Visitor posing as embodied interpretation in an art museum. Mind, Culture, and Activity, 21, 148-170.

Steier, R. (2020). Designing for joint attention and co-presence across parallel realities. In International Conference of the Learning Sciences (ICLS) Nashville 2020, Nashville.

Steier, R., \& Kersting, M. (2019). Metaimagining and embodied conceptions of spacetime. Cognition and Instruction, 37(2), 145-168.

Steier, R., Pierroux, P., \& Krange, I. (2015). Embodied interpretation: Gesture, social interaction, and meaning making in a national art museum. Learning, Culture and Social Interaction, 7, 28-42.

Stuedahl, D. (2019). Participation in design and changing practices of museum development. In K. Drotner, V. Dziekan, R. Parry, \& K. C. Schrøder (Eds.), The Routledge handbook of museums, media and Communication (pp. 219-231). London: Routledge.

Treimo, H. (2020). Sketches for a methodology on exhibition research. In P. Bjerregaard (Ed.), Exhibitions as research: Experimental methods in museums (pp. 19-39). Routledge.

Tzortzi, K. (2015). Museum space: Where architecture meets museology. Routledge.

Vavoula, G., \& Sharples, M. (2007). Future technology workshop: A collaborative method for the design of new learning technologies and activities. Computer-Supported Collaborative Learning, 2, 393-419.

vom Lehn, D., Sang, K., Glassborow, \& King, L. (2020). Exhibition design and professional theories: The development of an astronomy exhibition. In H. Lewi, W. Smith, D. vom Lehn, \& S. Cooke (Eds.), The Routledge international handbook of new digital practices in galleries, libraries, archives, museums and heritage sites (pp. 270-282). Routledge.

Vygotsky, L. S. (1978). Mind in society: The development of higher psychological processes. Harvard University Press.

Vygotsky, L. S. (1981). The instrumental method in psychology. In J. Wertsch (Ed.), The concept of activity in Soviet psychology (pp. 134-143). Sharpe.

White, A., \& Chen, E. (2020). China museum's digital heritage profile: An evaluation of digital technology adoption in cultural heritage institutions. In H. Lewi, W. Smith, D. vom Lehn, \& S. Cooke (Eds.), The Routledge international handbook of new digital practices in galleries, libraries, archives, museums and heritage sites (pp. 103-115). Routledge. 